\title{
Correspondence on Leptin Receptor Q223R Gene Polymorphism and Breast Cancer
}

\author{
Asian Pac J Cancer Prev, 23 (2), 377-377
}

\section{Dear Editor}

Dear Editor, the publication by Atoum et al., (2022) in the journal is very interesting. Atoum et al., (2022) found that $L E P R$ polymorphism Q223R GG genotype (Arg/Arg genotype) was linked to a higher leptin profile in obese breast cancer women (Atoum et al., 2022). This phenomenon is possible and might be explained by the change of molecular weight. For Arg/Arg genotype, the basic molecular weight (248.4) is less than those of Gln/Gln (292.28) or Arg/Gln (229.34) genotypes. Therefore, at the same mass, a less molecule for complete reaction to form leptin is required for Arg/Arg genotype. Hence, a higher level of leptin might be observed for Arg/ Arg genotype. Nevertheless, we should also recognize that there might also be other confounding effect that can alter the leptin level. Nutrition and metabolic disease can also affect leptin level (Stanhope, 2016). Also, there are other polymorphisms of leptin, which are not investigated by Atoum et al., that can result in high leptin level. The best example is Lys656Asn polymorphism (de Luis DA et al., 2013).

\section{Conflict of interest}

No conflict of interest.

Keywords: Leptin- receptor- polymorphism- breast-cancer

\section{References}

Atoum MF, Hamaid Alparrey AA (2022). Association of Leptin receptor Q223R gene polymorphism and breast cancer patients: A Case Control Study. Asian Pac J Cancer Prev, 23, 177-82.

de Luis DA, Aller R, Izaola O, Conde R, Eiros Bouza J (2013). Lys656Asn polymorphism of leptin receptor gene is related with leptin changes after a high monounsaturated fat diet in obese patients. J Investig Med, 61, 286-90.

Stanhope KL (2016). Sugar consumption, metabolic disease and obesity: The state of the controversy. Crit Rev Clin Lab Sci, 53, 52-67.

\footnotetext{
Amnuay Kebayoon ${ }^{1 *}$, Viroj Wiwanitkit ${ }^{2,3}$

${ }^{1}$ Private Academic Consultant, Samraong, Cambodia. ${ }^{2}$ Joseph Ayobaalola University, Ikeji-Arakeji, Nigeria. ${ }^{3} 75138 \mathrm{Dr}$ DY Patil University, Pune, India. *For Correspondence: amnuaykleebai@gmail.com
} 